gram variance data were not presented in the original article, those data were verified through comparisons to commercial software programs. ${ }^{4,5}$ No errors were found for any of the calculated statistics across all 40 operative procedures. These comparative data are presented in the Table.

Clearly, the purpose of providing this software to physicians and infectious disease departments is to permit a uniform method of calculating surgical-site infection rates, which should lead to a reduction of infectious morbidities in hospitals. By using this software, hospital infectious disease departments or staff can accurately and reliably use the method described by Culver ${ }^{1}$ to calculate the surgical-site infection rate for any operative procedure in their hospital or practice. Furthermore, use of this software package allows intrahospital comparisons of infection rates to be made for a wide variety of surgical procedures. Data provided by this package also can be fed back to the physicians performing these procedures, a method shown to reduce infection rates in high- and low-risk patients. ${ }^{1}$

Gamma statistics, like most association or correlation statistics, yield possible values from -1.00 to 1.00 . Significant results corresponding to high positive gamma values indicate that the presence of an infection is positively associated with the number of risk factors. In other words, this means that as the number of risk factors increases so does the infection rate. Likewise, it is possible to have significant negative gamma values, indicating that the number of infections is inversely related to the number of risk factors present. Nonsignificant gamma results are those with a numerical value around zero, which indicates that no association exists between risk factors and infection rate.

This software package will shorten the amount of time required for hospital infectious disease departments to perform these calculations on a monthly or yearly basis, while simultaneously supplying a valid and reliable database tool for the hospital.

\section{AVAILABILITY}

This software is available to any individual or institution that would like to use it for their own purposes, free of charge. If you use this software in any research reports, grant applications, or publications, please make a proper citation.

If your e-mail system can handle binary attachments, you may e-mail a request to Thomas.Wasser@lvh.com and receive the program by return e-mail. Please put "Gamma Program" in the subject line of your e-mail.

Otherwise, please send a request including (1) A DOS-formatted 3.5-inch diskette, (2) a letter requesting this specific surgical-site infection rate software program, and (3) a self-addressed envelope or diskette mailer with return postage. Send your request to Thomas E. Wasser, $\mathrm{PhD}$, Health Studies Department, Moyer House, Lehigh Valley Hospital, 227 North 17th Street, Allentown, Pennsylvania, 18104. The software will be copied onto your diskette and returned as soon as possible.

\section{REFERENCES}

1. Culver DH, Horan TC, Gaynes RP, et al. Surgical wound infection rates by wound class, operative procedure and patient risk index. Am J Med 1991;91(suppl 3B):152S-157S.

2. Goodman LA, Kruskal WH. Measures of association for cross classifications. J Am Stat Assoc 1954;49:732-764.

3. Siegel S, Castellan NJ. Nonparametric Statistics for the Behavioral Sciences. 2nd ed. New York, NY: McGraw-Hill Book Company; 1988:291298.

4. SAS Institute Inc. SAS/STAT User's Guide, 1 Version 6. 4th ed. Cary, NC: SAS Institute Inc; 1990:866.

5. Dixon WJ, ed. BMDP Statistical Software Manual, 1. Berkeley, CA: University of California Press; 1988:264-266,549-550.

\title{
OSHA Requests Information on Needlesticks
}

\section{Gina Pugliese, RN, MS Martin S. Favero, $\mathrm{PhD}$}

In the September 9, 1998, Federal Register, OSHA requested comment on engineering and work-practice controls to reduce the risk of injuries from contaminated needles and other sharps, which continue to be a concern in work settings where employees are exposed to bloodborne pathogens. OSHA is interested in strategies that have been implemented successfully in the work environment, including both work practices and devices designed to limit the risk of such injuries. Responses will be reviewed carefully and will assist OSHA in determining effective approaches to reducing percutaneous injury rates and what role the agency may have in these approaches. A series of questions are included in the notice.

Comments should be postmarked on or before December 8, 1998, to the Docket Officer, Docket No. H370A, Room N-2625, US Dept of Labor, 200 Constitution Ave NW, Washington, DC 20210; telephone, 202-219-7894. Comments of 10 pages or fewer may be transmitted by fax to (202) 219-5046, provided the original and three copies are sent to the Docket Office thereafter. Comments also may be submitted electronically at http://www.osha-slc.gov/ html/needle-form.html. Please be aware that information such as studies, journal articles, and so forth cannot be attached to the electronic response and must be submitted in quadruplicate to the above address. Such attachments must clearly identify the respondent's electronic submission by name, date, and subject, so that they can be attached to the correct response. For further information, contact Bonnie Friedman, Director, OSHA Office of Public Affairs, Room N-3647, US Department of Labor, 200 Constitution Ave NW, Washington, DC 20210; telephone, 202-219-8148.

FROM: US Department of Labor, Occupational Safety and Health Administration. Occupational Exposure to Bloodborne Pathogens: Request for Information. Docket No. H370A. Federal Register 1998;63(174):48250-48252. 